\title{
Aprender é uma viagem: reflexões marioandradianas sobre arte e educação
} Learning is a journey: Mário de Andrade's refletions

on art education

\author{
RICARDO ELIA DE ALMEIDA MAGALHÃES ID
}

\section{Resumo}

Este trabalho investiga dois objetos principais: o livro "O turista aprendiz", escrito por Mário de Andrade durante suas viagens pelo Norte e Nordeste do Brasil entre 1927 e 1929 e o projeto pedagógico "Parques Infantis" implementado pelo escritor na cidade de São Paulo entre 1935 e 1938. Destes dois objetos de pesquisa emergem pontos de contato, temas recorrentes que revelam a concepção de Mário de Andrade sobre arte e educação. Este artigo busca esmiuçar estes temas no intuito de revelar concepções que balizam o pensamento e o fazer artístico do autor neste período. No fim da década de 1920, Mário de Andrade fez duas viagens, uma para o Norte passando pelo Nordeste e outra para o Nordeste do Brasil. As suas impressões, concebidas como um diário de viagem e publicadas na década de $1970 \mathrm{com}$ o título "O turista aprendiz", buscam apreender a identidade brasileira, em suas múltiplas faces, através dos costumes e especificidades de cada local visitado. $\mathrm{Na}$ década de 1930, no período em que foi diretor do Departamento de Cultura da Prefeitura de São Paulo, Mário de Andrade pôs em prática um projeto de educação infantil denominado "Parques Infantis", no qual crianças realizavam atividades artísticas ao ar livre inspiradas em diversas manifestações culturais do Brasil. Assim, este trabalho busca ampliar o conhecimento acerca da História da Educação no Brasil e na América Latina, e nos permite refletir sobre assuntos de grande relevância para os dias de hoje referente às mobilidades, trocas culturais, identidade, diversidade, arte, imaginação e projetos educacionais.

Palavras-chave: Arte. Educação. Mário de Andrade. O turista aprendiz. Parques Infantis.

\footnotetext{
a Universidade do Estado do Rio de Janeiro. Mestre em Educação pelo Proped/UERJ. E-mail: ricardoelia@gmail.com

Rev. Caminhos da Educação: diálogos, culturas e diversidades, Teresina, v. 2, n. 3, p. 92-119, set./dez. 2020
} 


\title{
Learning is a journey: Mário de Andrade's reflections on art and education
}

\begin{abstract}
This work investigates two main objects: the book "O turista aprendiz" ("The apprentice tourist") written by Mário de Andrade during his travels in the North and Northeast of Brazil between 1927 and 1929 and the educational project "Parques Infantis" ("Playgrounds") implemented by the writer in the city of São Paulo between 1935 and 1938. From these two objects emerges points of contacts, themes that reveals Mário de Andrade's conception of art and education. This article seeks to scrutinize these themes in order to reveal concepts that guide the author's thinking and artistic practice during this period.

In the late $1920 \mathrm{~s}$, the leading author of modernism made two trips, one to the North and one to the Northeast of Brazil. His impressions, designed as a travel diary and published in the 1970s under the title "O turista aprendiz", seek to capture the Brazilian identity in its multiple faces through the customs and specificities of each place visited. In the 1930s, when he was director of the Department of Culture of the São Paulo's municipality. Mário de Andrade put into practice a children's education project called "Parques Infantis", in which children performed artistic activities inspired by various cultural manifestations of Brazil. These practices, besides promoting the diffusion of the national culture, stimulated the expression of the subjectivities of the children. The educational project "Parques Infantis" has assimilated characteristics present in the book "O turista aprendiz", as valuation of the sensorial and the imaginary, stimulus to the invention and emphasis on the diversity. After constructing his concept of Brazilian identity in a playful and inventive way in the mentioned book, the intellectual conceived an educational project in which he considered the child as cultural producer, based on the Brazilian cultural diversity. Thus, this work is important because of the current theme; seeks to broaden knowledge about the History of Education in Brazil and Latin America; and allows us to reflect on issues of great relevance to contemporaneity regarding mobility, cultural exchanges, identity, diversity, art, imagination and educational projects.
\end{abstract}

Key-words: Art. Education. Mário de Andrade. O turista aprendiz. Parques Infantis. 


\section{El aprendizaje es un viaje: reflexiones de Mário de Andrade sobre arte y educación}

\section{Resumen}

Este trabajo investiga dos objetos principales: el libro "O turista aprendiz" ("El turista aprendiz"), escrito por Mário de Andrade durante sus viajes en el norte y noreste de Brasil entre 1927 y 1929 y el proyecto educativo "Parques Infantis" ("Parques Infantiles") implementado por el escritor en la ciudad de São Paulo entre 1935 y 1938. De estos dos objetos de investigación surgen puntos de contacto, temas recurrentes que revelan la concepción del arte y educación de Mário de Andrade. Este artículo busca examinar estos temas para revelar conceptos que guíen el pensamiento y el trabajo artístico del autor durante este período.

A finales de 1920, el autor realizó dos viajes, uno al norte y noreste y otro al noreste en Brasil. Sus impresiones, concebidas como um diario de viaje y publicadas en el 1970 con el título de "O turista aprendiz", buscan aprehender la identidad brasileña, en sus múltiples rostros, a través de las costumbres y especificidades de cada sitio visitado. En el 1930, cuando fue director del Departamento de Cultura del Ayuntamiento de São Paulo, Mário de Andrade puso en marcha un proyecto de educación infantil llamado "Parques Infantis", en que los niños realizaban atividades artísticas al aire libre inspirado en diversas manifestaciones culturales en Brasil.

Por lo tanto, este trabajo es importante para el tema actual; busca ampliar el conocimiento sobre la historia de la educación en Brasil y América latina; y nos permite reflexionar sobre temas de gran relevancia para la actualidad en materia de movilidad, intercambios culturales, identidad, diversidad, arte, imaginación y proyectos educativos.

Palavras clave: Art. Educación. Mario de Andrade. O turista aprendiz. Parques Infantis.

\section{Introdução}

Em suas duas grandes viagens pelo Norte e Nordeste no final da década de 1920, Mário de Andrade considerou-se um turista em seu próprio país. Estranhou o familiar, familiarizou-se com o estranho. O devir viajante deste turista "descobre o Brasil" e imagina o seu próprio arranjo de nação, através de registros no diário, que mesclam fatos corriqueiros narrados e invenções do escritor. Os diários destas viagens transformaram-se algumas décadas depois no livro "O turista aprendiz", um dos objetos de estudo desta pesquisa.

Rev. Caminhos da Educação: diálogos, culturas e diversidades, Teresina, v. 2, n. 3, p. 92-119, set./dez. 2020 


\section{Aprender é uma viagem: reflexões marioandradianas sobre arte e educação}

Outro foco de investigação deste artigo foi implementado por Mário de Andrade alguns anos depois, no cargo de diretor do Departamento de Cultura da Prefeitura de São Paulo. É um projeto pedagógico que ensina música, dança e festejos do Norte e Nordeste para as crianças e adolescentes na capital paulista. Em espaços amplos e abertos, os "Parques Infantis" oferecem atividades artísticas que estimulam a imaginação das crianças e as considera como produtoras de cultura. Em um momento em que o movimento modernista do qual Mário fez parte construía sua ideia de Brasil baseada na antropofagia, na absorção de múltiplas influências, Mário de Andrade propõe um projeto de educação público e não escolar que pretende oferecer um currículo que inclui a cultura brasileira entre as atividades destinadas às crianças.

A promoção da ideia de "cultura brasileira" tinha ali um amparo governamental, em sintonia com o contexto de promoção da ideia de "nacionalismo" por órgãos estatais em grande parte do mundo ocidental no início do século XX. Os "Parques Infantis" constituíram-se como uma proposta pedagógica não escolar com foco na assistência, que mescla conceitos como identidade e arte, sob a perspectiva nacionalista e positivista.

No presente artigo, minha intenção é compartilhar os pontos principais da minha dissertação de mestrado defendida no Programa de Pós-Graduação em Educação da Universidade do Estado do Rio de Janeiro (UERJ) em 2018, com orientação da professora Alexandra Lima da Silva. Nesta dissertação, intitulada "Um turista aprendiz nos Parques Infantis: Mário de Andrade, viagem e educação”, tracei justamente pontos de contato entre o livro e o projeto pedagógico de Mário de Andrade e identifiquei temas recorrentes que relacionam arte, viagem e educação.

Enquanto o livro "O turista aprendiz" foi escrito durante as duas viagens de Mário de Andrade pelo Brasil, a primeira pelo Nordeste e Norte do Brasil em 1927 e a segunda pelo Nordeste entre 1928 e 1929, o projeto pedagógico "Parques Infantis" Rev. Caminhos da Educação: diálogos, culturas e diversidades, Teresina, v. 2, n. 3, p. 92-119, set./dez. 2020 
foi implementado na cidade de São Paulo entre 1935 e 1938. Tanto o livro quanto o projeto educacional estão inscritos no projeto de Mário de compor uma ideia de identidade brasileira. Relacionada com esta busca está a criação em 1936 do Anteprojeto de Preservação do Patrimônio Artístico Nacional, por Mário de Andrade. Este Anteprojeto deu origem ao Serviço do Patrimônio Histórico e Artístico Nacional (SPHAN), órgão federal criado em 1937 no governo de Getúlio Vargas. Posteriormente, este órgão tornou-se o Instituto do Patrimônio Histórico e Artístico Nacional (IPHAN), como o conhecemos até hoje.

As experiências vividas por Mário de Andrade em suas viagens na década de 1920 reverberaram na criação e execução da proposta pedagógica dos "Parques Infantis". Como atesta Luiz Philippe Peres Torelly no texto "O turista aprendiz e o patrimônio cultural", incluído na edição de 2015 do livro "O turista aprendiz", publicada pelo IPHAN:

Ao assumir a Diretoria do Departamento de Cultura da Prefeitura de São Paulo, em 1935, nosso modernista põe em prática muito do aprendizado de suas viagens. Empreende uma intensa atividade de difusão de manifestações culturais eruditas e populares, com forte viés educativo, 0 que acabou por polir suas formulações para elaborar, em 1936, o Anteprojeto de Preservação do Patrimônio Artístico Nacional, sob encomenda do então Ministro da Educação e Saúde do governo Getúlio Vargas, Gustavo Capanema. Conceitos como o de arte ameríndia e popular, bastante abrangentes, incluindo o que hoje denominamos de saberes, fazeres e falares, ou o de paisagem cultural - sem ainda receber esta denominação -, já estão presentes em sua proposta, o que lhe confere impressionante contemporaneidade após tantos anos. (ANDRADE, 2015, p. 12).

Ao nos debruçarmos sobre o livro e o projeto pedagógico, emergem pontos de contato, temas recorrentes que aproximam arte e educação sob um ponto de vista teórico. Este artigo é dividido em seções que representam estes temas e revelam um pouco da concepção de Mário de Andrade sobre arte e educação.

\subsection{Primitivismo moderno: povo, primitivo, criança.}

Figura 1 - Fotografia tirada por Mário de Andrade, durante a sua viagem para a Amazônia.

Rev. Caminhos da Educação: diálogos, culturas e diversidades, Teresina, v. 2, n. 3, p. 92-119, set./dez. 2020 


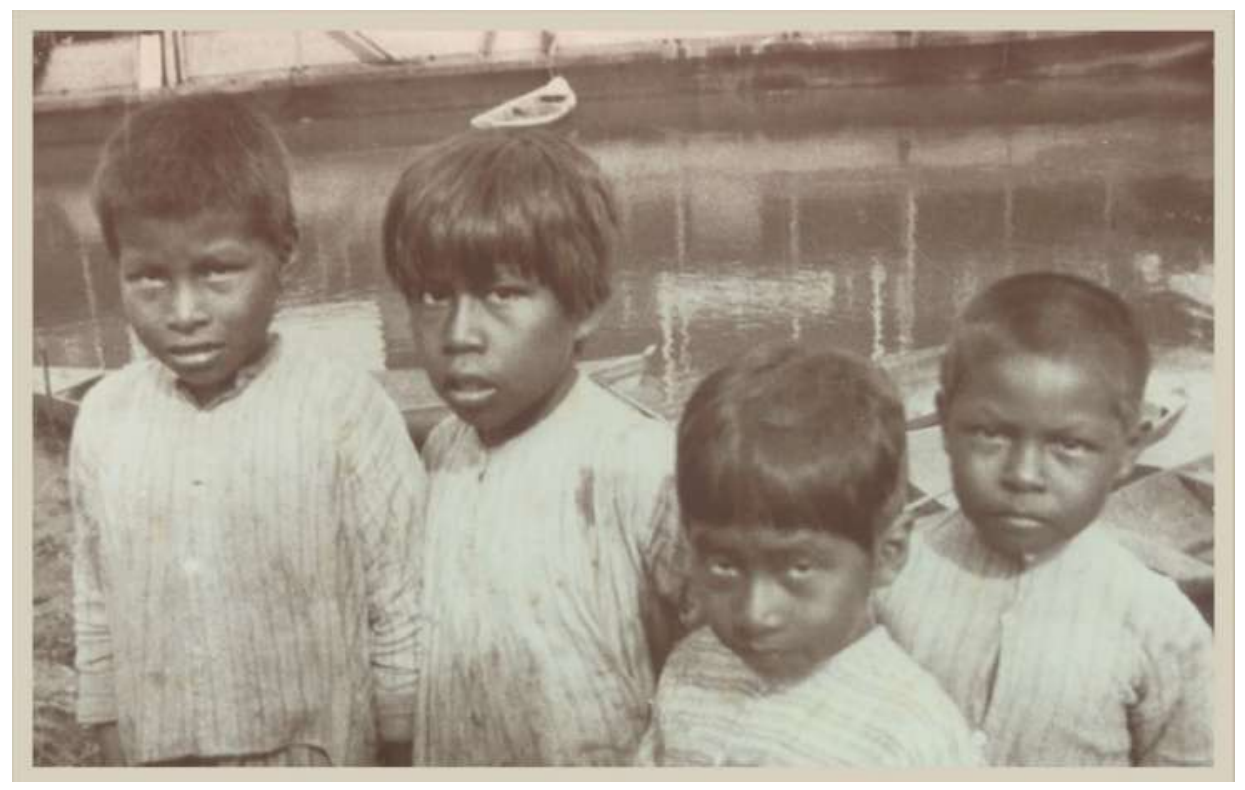

Legenda: Crilas de Assacaio

Alto Solimões, 17 de junho de 1927.

"... o homem que tirou a fotografia da gente..."

Fonte: CD-ROM - Os Diários do Fotógrafo. Contido no livro "O Turista Aprendiz", Iphan, 2015. Número no CD-ROM: 1927-151.

Tanto o livro "O turista aprendiz" como o projeto dos "Parques Infantis" reúnem reflexões acerca destes três temas: povo, primitivo e criança. Muitas vezes, os temas aparecem relacionados entre si nos escritos do autor, que traça paralelos entre eles. Ao longo de sua vida, Mário de Andrade demonstrou grande interesse em pesquisar sobre a arte dos "primitivos", arte do povo e arte produzida pelas crianças. Uma constante entre esses grupos é o fato de serem tratadas como vozes "menores" nas relações de poder vigentes no contexto em que viveu Mário de Andrade.

A abordagem dos temas nos escritos de Mário de Andrade revela uma "vontade de aproximação", uma afinidade em permanente tensão com uma separação evidente: Mário não podia ser considerado oriundo de classes populares, além de ser Rev. Caminhos da Educação: diálogos, culturas e diversidades, Teresina, v. 2, n. 3, p. 92-119, set./dez. 2020 
um adulto erudito. Mas é marcante no seu trabalho a curiosidade e o deslumbramento em relação aos três temas. E também suas próprias contradições e dualidades. Humanas e marioandradianas por natureza. Nas obras do autor, há um exercício contínuo de valorizar a diferença. Exercício de reconhecer no outro, qualquer que seja este "outro", um produtor de cultura digno de atenção. Traço que esta presente tanto no registro das viagens pelo Brasil quanto no projeto pedagógico "Parques Infantis".

O poema "Carnaval Carioca", dedicado a Manuel Bandeira, foi escrito por Mário em 1923, baseado nas suas experiências no carnaval de rua na cidade do Rio de Janeiro. Através de uma narrativa carregada de sentimento, o autor deixase levar pela multidão, misturando-se ao frenesi do povo que vibra coletivamente.

Como neste trecho do poema:

Eu mesmo... Eu mesmo, Carnaval...

Eu te levava uns olhos novos

Para serem lapidados em mil sensações bonitas,

Meus lábios murmurejando de comoção assustada

Haviam de ter puríssimo destino...

É que sou poeta

E na banalidade larga dos meus cantos

Fundir-se-ão de mãos dadas alegrias e tristuras, bens e males

Todas as coisas finitas

Em rondas aladas sobrenaturais.

(...)

Eu bailo em poemas, multicolorido!

Palhaço! Mago! Louco! Juiz! Criancinha!

Sou dançarino brasileiro!

Sou dançarino e danço! E nos meus passos conscientes

Glorifico a verdade das coisas existentes

Fixando os ecos e miragens.

Sou um tupi tangendo um alaúde

E a trágica mixórdia dos fenômenos terrestres

Eu celestizo em euritmias soberanas,

Óh encantamento da Poesia imortal!...

(PUCHEU, 2011, p. 8).

Sobre esta relação do autor com o carnaval carioca, que pode ser verificada através do trecho do poema acima, Alberto Pucheu comenta no livro " O carnaval carioca de Mário de Andrade":

Duas figurações de Brasil ou de brasileiros aqui se inscrevem: tanto a de um Brasil paulistaeuropeu-frio-erudito-preconceituoso em antagonismo com a heterogênea mestiçagem popular festivamente extática e cosmopolitamente aberta a todas as cores, a todas as nacionalidades, a

Rev. Caminhos da Educação: diálogos, culturas e diversidades, Teresina, v. 2, n. 3, p. 92-119, set./dez. 2020 
Aprender é uma viagem: reflexões marioandradianas sobre arte e educação

todos os tipos, a todos os lugares e a todos os tempos quanto a deste Brasil carioca, acolhedor daquele (e de muitos outros), que, desguarnecendo todas as fronteiras e identidades previamente demarcadas, leva-o a transformações necessárias. A transformação do primeiro no segundo é a construção que, no poema, Mário realiza de si e da imagem do Brasil que deseja implementar a partir de sua vivência no carnaval do Rio de Janeiro, mostrando que tal pujança brasileira provém antes do povo, que acata o erudito paulista (e todos os outros tipos em suas diferenças), do que de uma elite erudita para a qual o que provém do povo é, a princípio, uma "estupidez" animalesca e natural; se a pujança vem antes do povo, vem, de algum modo, também da elite erudita que busca superar seu julgamento preconceituoso, em decorrência de uma observação, de uma compreensão e de uma admiração que acabam possibilitando a imersão na dinâmica da festa popular e, consequentemente, na dinâmica do animalesco e do natural , ou melhor, do "supremo natural" do próprio povo, que goza. (PUCHEU, 2011, p. 41, grifo nosso).

A vivência de Mário de Andrade na rua, que desfila junto dos cordões carnavalescos - antepassados dos atuais blocos do carnaval carioca - inspira-o a refletir sobre as diferenças e pluralidades que formam a ideia de "identidade brasileira". O verso "Sou um tupi tangendo um alaúde" cria uma imagem que é em si uma mistura de identidades. "Tupi" designa um dos principais grupos indígenas do Brasil, cuja língua influenciou o português falado no Brasil. O alaúde é um instrumento de cordas de origem árabe, muito utilizado na Europa, principalmente na península ibérica.

Mário de Andrade, o autor da poesia "Eu sou trezentos", inspira-se pela diversidade, assume-se diverso, permite-se diverso. Absorve influências do carnaval carioca em 1923, e das viagens para Norte e Nordeste entre 1927 e 1929. A rua, o espaço público e coletivo, polissêmico, palco de fluxos diversos, é a matéria-prima fundamental de muitos dos seus escritos. A tônica de muitos textos provém da rua, característica que pode ser verificada em outros autores brasileiros, como por exemplo Paulo Barreto, conhecido como João do Rio, autor do livro "A alma encantadora das ruas" (1908).

A rua, o povo e a arte popular são temas constantes na obra de Mário e Andrade. A reflexão sobre a arte produzida por indivíduos que são considerados oriundos de camadas populares, aparece em suas cartas para Carlos Drummond de 
Andrade. Como é o caso deste trecho, escrito em 20 de fevereiro de 1927, meses antes de sua primeira viagem para a Amazônia:

Aliás sempre tive uma propensão imensa por tudo quanto é criação artística popular. Não só brasileira não. De toda a parte. Tenho uma coleção de músicas populares de toda a parte e sempre falei com escândalo de todos que jamais um compositor erudito inventou músicas tão bonitas como certas coisas do povo. $O$ povo tem isso que entre coisas sublimes bota uma porrada de coisas duma banalidade fatigante, porém isso é natural. Falta neles aquela dose de critério suficiente, aquela vontade-de-análise que deixa as obras dos artistas verdadeiros sempre intelectualmente interessantes mesmo quando não prestam. Acredito que essa minha propensão não vem de agora nem é efeito de moda. Sempre tive ela e para mim essas grandes lendas tradicionais dos povos são as histórias os casos os romances mais lindos que pode haver. Meu Macunaíma nem a gente não pode bem dizer que é indianista. $O$ fato dum herói principal de livro ser índio não implica que o livro seja indianista. A maior parte do livro se passa em São Paulo. Macunaíma não tem costumes índios, tem costumes inventados por mim e outros que são de várias classes de brasileiros. O que procurei caracterizar mais ou menos foi a falta de caráter do brasileiro que foi justamente o que me frapou quando li o tal ciclo de lendas sobre o herói taulipangue. Os caracteres mais principais que a gente percebe no livro são a sensualidade, 0 gosto pelas bobagens um certo sentimentalismo melando, heroísmo coragem e covardia misturados, uma propensão pra política e pro discurso. Porém nem tive intenção de fazer um livro importante de psicologia racial não. Fiz o que me vinha na cabeça unicamente me divertindo e nada mais. (ANDRADE, 1982, p. 103).

Nota-se que o autor, se em um trecho da citação acima enaltece a arte produzida pelo povo, em outro contrapõe a arte do povo à arte dos "artistas verdadeiros". Segundo Mário de Andrade, falta no artista popular “aquela vontadede-análise que deixa as obras dos artistas verdadeiros sempre intelectualmente interessantes mesmo quando não prestam”.

É interessante verificar a complexidade do olhar de Mário de Andrade sobre a arte produzida pelas camadas populares. Nota-se um esforço em seus textos de valorizar a arte popular produzida frente às artes eruditas, porém neste trecho revela sua percepção de que os artistas verdadeiros seriam os artistas eruditos.

Já no texto "Romantismo musical", uma conferência literária escrita em 1941 incluído no livro "O baile das quatro artes", vê-se também essa tríade articulação - povo, primitivo, criança - citando suas experiências vivenciadas na viagem de 1927:

No Amazonas, em certas regiões mais despidas do homem branco e de seringais, quando o navio de fundo chato subia arquejando, junto à margem, buscando os remansos por Ihe ser impossível vencer a corrente do meio do rio, às vezes eu escutava frágeis mas penetrantes assovios humanos, nascidos do mato sem ninguém. Outros assovios secundavam longe. Me explicaram serem tapuios mestiços semicivilizados, totalmente inofensivos, se entrecomunicando a respeito do navio que vinha. Eu escutava essa música... romântica, simples conversa entre tapuios; e si, por um lado, pra eles essa música era uma real conversa econômica de vida social, por outro lado, Rev. Caminhos da Educação: diálogos, culturas e diversidades, Teresina, v. 2, n. 3, p. 92-119, set./dez. 2020 
Aprender é uma viagem: reflexões marioandradianas sobre arte e educação

ela me falava, não tem dúvida nenhuma que falava ao consciente, com uma violência associativa enorme, em que era muito Hans Staden, quase um i-juca-pirama, e um bocado também, desculpem, Ceci salva das águas num bom navio confortável. Se conta ainda que, no Nordeste, por meio dos seus cantos de aboiar, os vaqueiros chegam às vezes a se corresponder de engenho a engenho, de fazenda a fazenda, se dizendo coisas e dizendo coisas aos seus bois. Poderia multiplicar ao infinito os exemplos e lembrar a musicalidade das linguagens infantis e dos primitivos. E todas estas músicas românticas, cujas palavras são frequentemente puros sons inarticulados, às vezes musicalíssimos, têm uma origem legítima, têm uma base biológica natural, o grito. 0 grito primitivo dos primeiros homens - esse um só grito de que provieram os sons inarticulados e os sons articulados, o ré bemol e a palavra, a música e o verbo. (ANDRADE, 1963, p.38, grifo nosso).

No mesmo texto " Romantismo musical”, incluído no livro "O baile das quatro artes", Mário de Andrade, em trecho posterior, ao comentar sobre a proposta estética musical do Romantismo, relaciona a arte dos primitivos à arte das crianças:

É nos românticos que a gente vai encontrar à larga esse poético musical, essa aura divagante e indefinível que, embora dela nascendo, na verdade transcende a fenomenologia sonora e parece independer dela. Desde as primícias de certo Mendelssohn sinfônico, de certo Weber operístico e mesmo de certo Lesueur cantando os "Bardos", e desde também a melódica de um Bellini, flébil e indestinada, as manifestações musicais frequentemente parecem se destacar da própria música, para adquirir uma profunda forma evocativa. É constante agora nas obras, desde o início do Oitocentos, por mais bem-compostas e dentro da técnica erudita, esse valor que encontramos com tanta frequência nas criações dos artistas que independem da técnica, os primitivos em geral, os desenhos de crianças, os poemas dos loucos: um profundo sabor evocativo, uma transcendência lírica, iluminada e fantasmática. (ANDRADE, 1963, p. 48, grifo nosso).

$\mathrm{Na}$ proposta pedagógica dos "Parques Infantis", estimular as crianças a produzirem arte era parte fundamental da pesquisa estética de Mário de Andrade, da sua pesquisa em busca da essência da arte. Essência esta que relaciona-se com "um profundo sabor evocativo, uma transcendência lírica, iluminada e fantasmática”. O que Mário valorizava na arte em seus escritos era esta essência, esta transcendência lírica encontrada na arte dos primitivos, dos povos e das crianças. Essa pulsão criadora, este sentimentalismo não racional, "aura divagante e indefinível".

Ao considerar as crianças como sujeitos produtores de cultura, além de receptores, o fazer artístico infantil foi valorizado e estimulado. Mário reuniu acervo 
de desenhos das crianças produzidos nos "Parques Infantis" e os percebia de forma crítica, com olhos de pesquisador.

O "primitivismo moderno" da Semana de 1922 manifesta-se justamente em uma proposta estética que baliza-se na ruptura, na busca de novos caminhos. Primitivismo que, no campo da poesia, por exemplo, está relacionado à adoção dos versos livres pelos poetas modernistas. Segundo Mário de Andrade: “O verso livre é justamente aquisição de ritmos pessoais (...) é uma vitória do individualismo" (ANDRADE, 1978, p. 278). O primitivismo moderno significava a abertura de caminhos para uma nova fase na produção de artes no Brasil:

O modernismo, o primitivismo moderno, como diz o Prefácio ${ }^{1}$, é uma abertura de possibilidades, uma tentativa de dar futuro, de abrir caminho a uma nova fase construtiva. Se a perfeição em arte é uma destruição do futuro, e se a questão do modernismo era a possibilitação de um futuro, era preciso que a obra desse modernismo fosse algo como uma absoluta imperfeição, um total não fazer-se. E que a cada passo seu ela devesse se desculpar, se autodestruir, se negar. ( PUCHEU, 2011, p. 110).

As dicotomias "perfeição x imperfeição", "arte erudita x arte popular" aparecem com frequência nos ensaios de Mário de Andrade sobre arte. O modernismo, o "primitivismo moderno" trazia a marca da imperfeição se comparado ao Parnasianismo, escola com a qual se identificaram grande parte dos poetas brasileiros do início do século XX. No trecho abaixo, o Parnasianismo é representado na figura do poeta Olavo Bilac. Segundo Mário de Andrade:

O apogeu já é decadência, porque sendo estagnação não pode conter em si um progresso, uma evolução ascensional. Bilac representa uma fase destrutiva da poesia; porque toda perfeição em arte significa destruição (...) O nosso primitivismo representa uma nova fase construtiva. (ANDRADE, 1980, p. 26 apud PUCHEU, 2011, p. 110).

O primitivismo de Mário de Andrade manifesta-se na aceitação da imperfeição na arte, uma ruptura dos padrões vigentes que abrisse a arte para novas possibilidades de futuro. A identidade do movimento modernista aponta para a própria abertura de identidades, a riqueza dessa abertura. (PUCHEU, 2011, p. 132). O povo, o primitivo e a criança simbolizam, de certa forma, esta "imperfeição" na produção de arte. Mas como já dito, trata-se de uma imperfeição que constrói, que abre caminhos para o novo. Uma imperfeição criadora.

\footnotetext{
${ }^{1}$ Prefácio do livro "Losango Cáqui", de Mário de Andrade, publicado em 1926.

Rev. Caminhos da Educação: diálogos, culturas e diversidades, Teresina, v. 2, n. 3, p. 92-119, set./dez. 2020
} 
Aprender é uma viagem: reflexões marioandradianas sobre arte e educação

No modernismo, o primitivismo também é representado pelo artista que faz arte com uma finalidade social, uma "arte interessada". Como neste trecho em que Mário se compara a um "homem das cavernas quaternárias":

Minha arte, se assim você quiser, tem uma função prática, é originada, inspirada dum interesse vital e pra ele se dirige. Nisto sou tão primitivo como um homem das cavernas quaternárias. Só que além do interesse por assim dizer físico, interesse sexual, interesse de socialização, tenho ainda um interesse espiritual mais largo que o dele que só se dirigia aos deuses amedrontadores. Ainda é preciso distinguir entre primitivismo e primitivismo. Tem o que vem da precariedade técnica. Condenável. Tem o que vem da exata realização psíquica (Negros, Bizâncio, Puvis de Chavannes, Aleijadinho). Admirável e louvável. Tem o que vem da consciência duma época e das necessidades sociais, nacionais, humanas dessa época. É necessário. É intelectual, não abandona a crítica, a observação, a experiência e até a erudição. E só aparentemente se afasta delas. É o meu. É necessário. Minha arte aparente é antes de mais nada uma pregação. Em seguida é uma demonstração. (ANDRADE, 1982, p. 25).

Para o autor, a arte primordialmente tem finalidade social, relaciona-se à coletividade. Tal qual a função da música no carnaval, que reúne e movimenta multidões, é a função da arte para o autor, que é comparada a uma pregação.

\subsection{Imaginação e sensação}

Tanto no livro "O turista aprendiz" quanto nos "Parques Infantis", a imaginação e a sensação foram constantemente utilizadas como ferramenta de estímulo. Para o leitor, no caso do livro. E para os alunos, no caso do projeto pedagógico. Nos "Parques Infantis”, imaginação e sensação eram estimuladas através de atividades de desenho, teatro e música. No livro, estão na forma de descrever as experiências vividas em primeira pessoa pelo turista aprendiz. Como destacam Telê Ancona Lopes e Tatiana Longo Figueiredo na introdução da edição da obra lançada em 2015 pelo IPHAN:

No procedimento de inventar, o narrador do diário, consciente de seus limites de viajante e dos ilimitados recursos da imaginação, suplanta criticamente o verídico por meio da verossimilhança, Rev. Caminhos da Educação: diálogos, culturas e diversidades, Teresina, v. 2, n. 3, p. 92-119, set./dez. 2020 
no jogo sutil e irônico que surpreende a realidade também em uma dimensão grotesca, degradada. Em verdade, a transviagem blinda os dois diários de viagem: aparta-os da narração convencional, do vezo de taxar de exótico ou pitoresco tudo o que difere do conhecido, do convencional. O diarista cria, então, bancando um etnólogo como o Koch-Grünberg2 das leituras do Mário de Andrade, excursões a povos indígenas cuja cultura inventa, como os dó-mi-sol, imersos em um universo de sons musicais e em sua "moral distinta da nossa", povos que poderiam suscitar uma "monografia humorística, sátira às explorações científicas, à etnografia e também social", servindo-se da irreverência de laivos dadaísta. (ANDRADE, 2015, p. 38).

A narração de Mário de Andrade no livro "O turista aprendiz" intervém na "realidade" experimentada. O narrador do diário é também um "eu-lírico": inventa, molda, participa das experiências narradas. Assume-se como criador do discurso. Trata-se de uma etnografia produzida através de narrativa autoral que aceita a subjetividade do pesquisador como mediadora na produção do conhecimento. Mário de Andrade pode ser visto como um personagem de transição entre dois modelos de etnografia. Um destes modelos produzido através de coleta de material e descrição objetiva e o outro modelo que além destes meios acata a subjetividade do pesquisador como criadora de conhecimento.

Em texto escrito em 28 de junho de 1927 no diário "O turista aprendiz", viajando de barco pela floresta amazônica no trecho fronteiriço entre Brasil e Peru, Mário aborda os índios dó-mi-sol, uma tribo inventada pelo autor. Esta passagem é um exemplo desta mistura entre descrição das experiências vividas e da imaginação de Mário de Andrade no diário. Abaixo o trecho:

\section{Os índios dó-mi-sol}

Eu creio que com os tais índios que encontrei e têm moral distinta da nossa, posso fazer uma monografia humorística, sátira às explorações científicas, à etnografia e também social. Seria a tribo dos índios dó-mi-sol. Será talvez mais rico de invenções humorísticas, dizer que eles, em vez de falarem com os pés e as pernas, como os que vi, em vez, no período pré-histórico da separação do som, em som verbal com palavras compreensíveis e som musical inarticulado e sem sentido intelectual, fizeram o contrário: deram sentido intelectual aos sons musicais e valor meramente estético aos sons articulados e palavras. O nome da tribo, por exemplo, eram os dois intervalos ascendentes, que em nosso sistema musical, chamamos dó-mi-sol.

É na subida do Madeira que encontro os índios dó-mi-sol. Assim evita, durante a subida a mínima descrição de paisagem, que farei só na descida que é mais rápida. É um paroara que encontro cantando na terceira. Fica meu amigo e um dia pergunta se quero ver uma coisa. Me diz pedir ao comandante uma parada logo ali adiante, na boca dum igarapé e me leva conhecer o tal povo. Dar fisiologia desses índios, toda inventada. Descrever as cerimônias da tribo, suas relações tribais, família, fratrias etc. Religião. Sua filosofia e maneira de discutir. Seu comunismo. No fim, dar uma série de lendas, de pura invenção minha. As lendas etiológicas, se prestam muito para a fantasia. Dar um vocabulário também ficava engraçadíssimo, se prestando a efeitos muito

\footnotetext{
2 Theodor Koch-Grünberg (1872-1924) foi um etnologista e viajante alemão que estudou os povos indígenas da América do Sul. Mário de Andrade refere-se a este explorador na obra Macunaíma, de 1927.

Rev. Caminhos da Educação: diálogos, culturas e diversidades, Teresina, v. 2, n. 3, p. 92-119, set./dez. 2020
} 
humorísticos, mas só poderiam perceber isso os que soubessem música. $\mathrm{E}$ os músicos em geral são tão pouco perspicazes... É melhor desistir do vocabulário. (ANDRADE, 2015, p. 133).

No trecho, o autor assume-se como inventor da tribo e de suas lendas. "Eu creio que os índios que encontrei e têm moral distinta da nossa, posso fazer uma monografia humorística, sátira às explorações científicas, à etnografia e também social". Esta sátira engloba reflexões de Mário sobre as origens da comunicação humana, relacionando palavra e música: um grupo indígena que se comunica através de notas musicais. Músico e musicólogo que era, muitos dos seus textos foram dedicados a investigar a relação entre "linguagem" e "música", questionando sobre relações primordiais entre o som e o sentido ${ }^{3}$. É o caso da conferência literária "Romantismo musical", escrita em 1941 e incluída no livro "O baile das quatro artes". No trecho abaixo, podemos notar a exposição de fundamentação teórica, reflexões que relacionam-se com a ficção dos "Os índios dó-mi-sol":

Agora suponhamos: si quando os seres humanos principiaram se servindo da emissão vocal para expressar as primeiras imagens e ideias (que, si não me engano muito, foram "meu" e "eu quero"...), si, em vez de roucos sons articulados, tais forças primordiais da vida se expressassem convencionalmente por sons musicais, mais ou menos equiparáveis a um sol ou fá contemporâneos; si logo em seguida as ideias coletivistas da "amiga" e do "amigo" se tivessem tornado conscientes ao homem peludo pela convenção de intervalos, bons intervalos ascendentes por certo e bem dinâmicos, a "amiga" no mais trabalhoso intervalo de quinta, dó-sol, e o "amigo" mais conclusivamente no intervalo sol-dó, assim se completando a base pacífica das nossas harmonias sociais; si, enfim, tivessem os primeiros homens escolhido convencionalmente os sons musicais para dicionarizar na consciência as imagens e os juízos: nós hoje estaríamos nos comunicando uns com os outros por meio de árias e cantiguinhas, melodias infinitas, hinos e até marchas totalitárias, ao passo que viríamos a concertos escutar a divina arte pura do palanfrório, bulhas escancaradas de mercados e os discursos políticos. Seria triste... Mas devo estar romantizando.

A música não sabe nem conseguirá jamais saber quais os seus limiares expressivos. É tão forte e de tal forma imprevisível o seu dinamismo encantatório e o seu poder associativo e metafórico, que ela, si não consegue se realizar em juízos definidos dentro de nossa compreensão, no entanto vaporosamente se divulga, se derrama por muitos escaninhos da nossa consciência e assume, não as formas, porém os fantasmas e os mais profundos avatares do juízo. (ANDRADE, 1963, p. 39).

Nesta invenção de uma tribo, Mário de Andrade faz a exposição de reflexões profundas entre som e sentido. Sua fantasia dialoga com a cientificidade, mesclando

\footnotetext{
3 Para mais reflexões sobre o tema, ver livro "O som e o sentido", de José Miguel Wisnik, Companhia das Letras, 1989.

Rev. Caminhos da Educação: diálogos, culturas e diversidades, Teresina, v. 2, n. 3, p. 92-119, set./dez. 2020
} 
pesquisa e arte. Segundo a nota de número 26 presente no livro "O turista aprendiz" publicado em 2015 pelo IPHAN, edição de texto apurado, anotada e acrescida de documentos por Telê Ancona Lopez e Tatiana Longo Figueiredo:

26 O diário, quando o viajor alucina ao navegar pela ficção, funde personagens reais e fictícios, do passado e do presente, no tempo imemorial de tonalidade surrealista associado ao espaço sem fronteiras geográficas, solução praticada em Macunaíma, que MA está escrevendo desde 1926 e publicará em 1928. As notas, na presente edição de O Turista Aprendiz, focalizam elementos da criação do diário paralela à da rapsódia, o que significa a exploração de aspectos de um projeto estético, ideológico e linguístico no modernismo brasileiro. (ANDRADE, 2015, p. 58).

Além de entremear na narrativa personagens reais e fictícios, outra característica de Mário no diário foi não respeitar a realidade geográfica dos locais, misturando espécies vegetais e paisagens. Neste ato de "desgeograficar"4 o Brasil, nesta desregionalização territorial, Mário visita outros "territórios". É a imaginação do autor que mapeia o espaço segundo sua própria fantasia. Misturando localidades, deslocando espaços, a desregionalização busca diluir, fundir os brasis em um só Brasil. Mário de Andrade deseja nacionalizar o país através da literatura.

Há uma passagem de "O turista aprendiz", escrita em 18 de maio de 1927, que suscita uma nota das autoras que aborda justamente da desregionalização do Brasil feita na obra por Mário de Andrade. O trecho em questão descreve a paisagem vista pelo autor, em um estilo de narrar influenciado pelo surrealismo e pelas vanguardas europeias do início do século XX. No trecho está presente a fantasia do autor, seu olhar é cocriador de realidades:

O avanço do rio e o embate das águas formavam rebojos e repiquetes tremendos cujas ondas rebentavam na altura de sete metros chovendo espumas espumas espumas rosadas pela manhã do Sol. Por isso o Pedro I avançava numa chuva em flor. Avançava difícil, corcoveando aos saltos, relando pelo costado dos baleotes e das sucurijus de mato amazônico aventuradas até ali pela miragem da água doce. À medida que a gente se aproximava as ilhas catalogavam sob as cortinas de garças e mauaris que o vento que o vento repuxava todas as espécies vegetais e na barafunda fantástica dos jequitibás perobas, pinheiros plátanos assoberbada pelo vulto enorme do baobá a gente enxergava dominando a ramada as seringueiras sonhadas em cujas pontas mais audazes os colonos suspensos em cordas de couro cru apanhavam as frutinhas de borracha 49. (ANDRADE, 2015, p. 66).

Sobre este trecho, a nota 49 registra:

\footnotetext{
${ }^{4}$ Neologismo criado por Mário de Andrade, presente no prefeacio a Macunaíma (1928). (PUCHEU, 2011, p. 143).

Rev. Caminhos da Educação: diálogos, culturas e diversidades, Teresina, v. 2, n. 3, p. 92-119, set./dez. 2020
} 
490 trecho externa o nonsense rabelaisiano ou o disparate da literatura oral na enumeração de cunho surrealista. Na criação ficcional e poética de MA, a vegetação que despreza a realidade geográfica aparece pela primeira vez em dezembro de 1919, em "O queijo", na revista paulistana A Cigarra (a. 6, no 126), conto no qual o paraíso imaginado para as almas de escol reúne árvores de todas as partes do mundo. Em 10 de outubro de 1926, a propósito da leitura de seu poema "Lenda do céu", feita por Bandeira, MA declara: "É de fato um céu cabocolinho que quero descrever porém depois já ajuntei mais uma coisa: quero um céu cabocolinho que reúna o Brasil em coisas de Norte a Sul e também represente a civilização, isto é, o atual de certas partes caboclas do Brasil" (V. MORAES, Marcos Antonio de. (Org.). Op. cit., p. 314). Em 19 de dezembro,1926 na anotação de trabalho vinculada ao primeiro "Prefácio" esboçado para Macunaíma, o modernista afirma: "Um dos meus interesses foi desrespeitar lendariamente a geografia e a fauna e flora geográficas. Assim desregionalizava o mais possível a criação ao mesmo tempo que conseguia o mérito de conceber literariamente o brasil como entidade homogênea -um conceito étnico nacional e geográfico". (ANDRADE, 2015, p. 66).

Portanto, misturar as paisagens brasileiras relaciona-se com o projeto de nacionalismo universalista do grupo modernista, que dirigiu-se a "conceber literariamente o brasil como entidade homogênea - um conceito étnico nacional e geográfico". Tendência esta que era de certa forma contrária ao Regionalismo, por intentar centrar a visão de Brasil no "todo" e não nas "partes".

No livro "O turista aprendiz", um dos recursos utilizados por Mário de Andrade na sua "apreensão de Brasil" e na sua particular "construção de brasilidade" é a imaginação. Na busca de absorver, apreender o contexto amazônico em que vivia, inventa uma tribo. Sua postura é ativa frente à realidade. Nos "Parques Infantis", o projeto pedagógico inclui atividades que estimulam a participação ativa e criadora das crianças, principalmente atividades de produção de arte. Estas atividades não são encaradas como mera recreação apenas, tendo em vista que Mário de Andrade reuniu um acervo com os desenhos infantis onde anotava características dos desenhos com um olhar de pesquisador. As atividades dos "Parques Infantis" estavam relacionadas com o exercício de criação de identidades. Tanto a identidade brasileira, em âmbito geral, como a identidade de cada criança, em âmbito particular. As crianças eram percebidas nos Parques como sujeitos criadores de arte, sujeitos únicos em suas próprias diversidades. 
Figura 2 - Crianças desenhando nos "Parques Infantis".

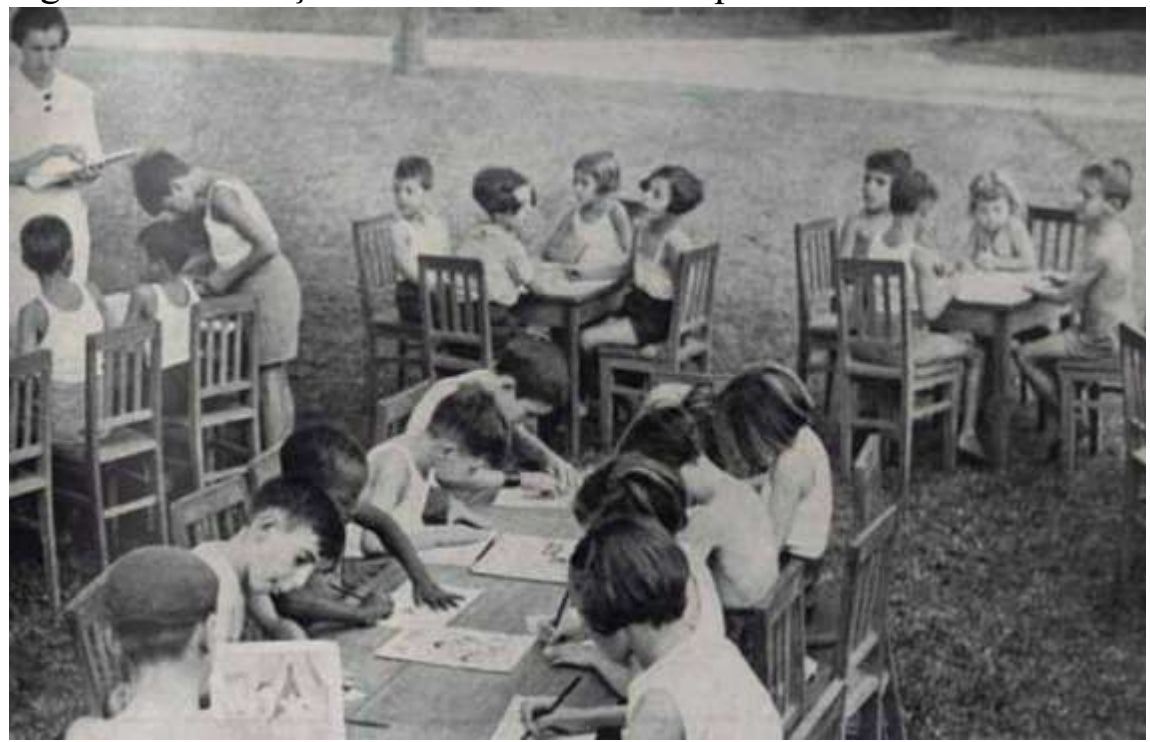

Fonte: Mário de Andrade e os Parque Infantis, Itau Cultural, 2013.

Daí o paralelo entre uma identidade brasileira em construção, "engatinhando" e o foco na produção artística das crianças. Torna-se possível inferir que a intenção de Mário de Andrade foi estimular a criação da "brasilidade" com a participação das crianças, que cresceriam e tratariam de expandir essa ideia de identidade nacional brasileira. Nos "Parques Infantis", crianças de diversas origens habitantes da cidade de São Paulo, que interfeririam neste processo de construção da identidade brasileira. A proposta das atividades dos "Parques Infantis" foi convidá-las para que entrassem em contato com músicas, danças, poesias (mousiké) que Mário colheu em suas viagens pelo Norte e Nordeste, que foram o seu próprio recorte, subjetivo é claro, amostra do que faria parte da "brasilidade" para o autor. Da percepção subjetiva de Mário de Andrade e dos responsáveis pela implementação dos "Parques Infantis", as crianças adicionariam suas próprias invenções e intervenções nesta ideia de brasilidade. Para que as crianças aprendessem sobre o Brasil, estimulou a criatividade delas. Um aprendizado, uma apreensão de Brasil através da criação. E então, a brasilidade estaria "viva", "em fluxo".

No livro "O turista aprendiz", Mário de Andrade deu vasão à sua própria criatividade na apreensão do Brasil que vivenciava diariamente. Nos "Parques 
Infantis", convidou a criatividade das crianças para tomar parte na apreensão da identidade brasileira.

Como criar uma identidade a partir de um país com tantas diferenças? Admitindo que a diferença seria um dos principais traços formadores da identidade brasileira.

Nesse sentido, trata-se da percepção de que para fazer parte de um modelo identitário - neste caso, a brasilidade- era preciso inventar, relaciona-se com a definição de tradição do artista italiano Bruno Munari, conforme trecho abaixo:

A cultura popular é uma manifestação contínua de fantasia, criatividade e invenção. Os valores objetivos destas atividades são acumulados naquilo que se chama tradição, técnica ou arte, como se queira. E estes valores são continuamente aferidos por outros actos de fantasia e de criatividade e, portanto, substituídos quando se mostram ultrapassados. Assim, a tradição é a soma, em contínua transformação, dos valores objetivos úteis para as pessoas. Limitar-se a repetir um valor, sem fantasia, não significa continuar a tradição, mas travá-la, fazê-la morrer. A tradição é a soma dos valores objetivos da colectividade e a colectividade deve renovar-se continuamente, se não quiser depauperar-se. (MUNARI, 2007, p. 39).

A continuação da tradição, portanto, dependeria da renovação. Esta renovação foi tônica do movimento Modernista e estava presente no projeto pedagógico "Parques Infantis", como também no livro "O turista aprendiz". Ter crianças e adolescentes como público-alvo dos "Parques Infantis" potencializa e traduz este desejo de renovação.

Além da imaginação, a sensibilidade das crianças foi estimulada nos "Parques Infantis" através das atividades de produção artística. No livro "O turista aprendiz", as sensações do autor foram valorizadas e permearam a narrativa, dando vida às experiências narradas pelo viajante aprendiz.

Um exemplo está na passagem escrita em 10 de maio de 1927, no Rio de Janeiro, de onde Mário embarcou rumo ao Nordeste e Norte do país:

Visto assim do mar, o Rio iluminado da noite é alucinante. Uma alucinação que se mexe com rapidez, pra ser bem explícito. Me deixo levar. A água geme oleosa, pesadíssima, refletindo 
devagar a iluminação assanhada das praias. Se sente festa nas praias, estão dando por aí um grande baile romântico, me sugerido pela ilha Fiscal. (ANDRADE, 2015, p. 56).

No trecho, a água adquire vida, "geme", é personificada pelo autor. Poesia, imaginação e sensação estão entremeadas com a narração do diarista. Imaginar, portanto, e sentir, foram encarados por Mário de Andrade como um dos caminhos para aprender. Esta relação entre educação e sensibilidade aparecem em uma passagem do italiano Bruno Munari, quando reflete acerca do contato de alguém com uma obra de arte:

Entender ou compreender? O maior obstáculo à compreensão de uma obra de arte é o de querer entender. Com uma frequência demasiada, entender significa selecionar e dar definições que enquadram a obra em um esquema predefinido, compreender é, ao contrário, possuir com os próprios meios, entrando em contato estreito que deixará marcas indeléveis, fixadas na memória através vivência emotiva. Uma eficaz metodologia de abordagem das obras de arte, mediante atividade de pesquisa e aprofundamento teórico para conectar-se às experiências concretas de produção individual e coletiva em situação de oficinas. (MUNARI, 1981, p. 7 apud ZUCCOLI, 2015, p. 1049).

Deste modo, Bruno Munari destaca no trecho a participação do espectador no processo de aprendizado. A necessidade de experimentação, de vivência do objeto de estudo para que se possa compreender e não apenas entender.

\subsection{Aprender é uma viagem}

"Toda viagem se destina a ultrapassar fronteiras, tanto dissolvendo-as como recriando-as $5 "$.

Podemos perceber através destas reflexões o quanto aprendizado, imaginação e sensação estiveram relacionados no livro e no projeto pedagógico analisados neste artigo. Algumas perguntas emergem: o quanto o aprendizado tem de invenção? $\mathrm{O}$ quanto aprender tem a ver com sentir? O quanto aprendemos através da criação? No livro, ao construir seu diário de viagens entremeado por invenções e textos que

\footnotetext{
${ }^{5}$ IANNI, Octavio. "A metáfora da viagem". In: Enigmas da modernidade-mundo. $3^{\mathrm{a}}$ ed. Rio de Janeiro: Civilização Brasileira, 2003, p. 13.

Rev. Caminhos da Educação: diálogos, culturas e diversidades, Teresina, v. 2, n. 3, p. 92-119, set./dez. 2020
} 
valorizam as sensações do eu-lírico, Mário coloca-se como ator participante de sua "descoberta de Brasil".

Ao "descobrir o Brasil" e as diferenças que seu próprio país lhe proporciona, ao sentir-se um estrangeiro em sua própria pátria, Mário de Andrade acaba aprofundando o conhecimento sobre si mesmo, processo que compartilha com seus leitores no diário. O autor reflete sobre hábitos dos grupos humanos que encontra, colocando-se em face da diferença, relacionando o mundo que está fora de si (experiência) e o mundo dentro de si (imaginação). Questionando o "europeu cinzento e bem arranjadinho" dentro de si:

O viajante metropolitano posto em contato, no espaço amazônico, com o desmesurado "na magnificência daquela paisagem feita às pressas", com situações incomuns perante a expectativa do "europeu cinzento e bem arranjadinho que ainda tenho dentro de mim", segue dois caminhos no diário, negando, em ambos, a minúcia documental. No primeiro caminho, elege a ficção para transfigurar uma realidade que o desnorteia, impondo-lhe o insólito, o estranho e o maravilhoso; que amplia até mesmo as fronteiras do surrealismo, ao lhe escancarar o inusitado em um mundo novo, em nada europeu, no qual vive um peixe-boi e gaivotas assassinam um homem na praia do Juma. Nesta sua obra inacabada, cuja escritura, como já se sabe, vai de 1927 a 1945, Mário consagra a exploração do real maravilhoso da América, conceito que o cubano Alejo Carpentier postularia, em 1949, no "Prólogo" de seu romance El reino de este mundo. Aliás, não só na viagem à Amazônia o insólito reside, pois, nas crônicas produzidas no Nordeste, tem-se o episódio da aranha, o caso de D. Clotildes e o estranho comportamento do guaxinim do banhado.

No segundo caminho, ao reconhecer os momentos nos quais a emoção o avassala, o Turista carreia para o diário a crônica da entrega plena, lirismo que ultrapassa a contemplação (...) (ANDRADE, 2015, p. 38).

Imaginando e sentindo, o turista apreende o entorno. Deixando de lado a minúcia documental em seu diário, interessa mais expressar sua subjetividade em face do que experimenta do que tentar descrever objetivamente o que vivencia. $\mathrm{O}$ título do diário, não é por acaso "O turista aprendiz". Ser aprendiz o coloca numa posição de abertura para o novo, de ousadia. O turista, tal qual um aprendiz, está aberto, repleto de curiosidade. "Todo viajante é boquiaberto por definição" aponta Carlos Drummond, o amigo epistolar de Mário de Andrade, neste trecho de "Confissão de Minas". 
Há, é certo, os lugares históricos e os pseudo-históricos, que a memória vaidosa do povo indica ao viajante boquiaberto (todo viajante é boquiaberto por definição). Mas não são eles em Sabará que nos despertam a melhor emoção; a melhor emoção, a mais cheia de pudor e a mais profunda, é para certas formas de beleza que o homem e o tempo criaram e vão destruindo de parceria; certas igrejas que envelheceram caladas e orgulhosas no seu incomparável silêncio; certos becos; certas ruas tristes e tortas por onde ninguém passa, nem a saudade deste chafariz, com uma cruz e uma data, como um túmulo; a sucessão dos Passos; muros em ruína mesmo, sem literatura, inteiramente acabados; tudo o que no passado não é nem epopeia nem romance nem anedota; o que é arte." (ANDRADE, 2011, p. 132).

Para o olhar alcançar o que o autor aponta neste trecho como "arte", é necessária esta abertura de olhar. Abertura de um olhar aprendiz, sem préjulgamentos, aberto para o agora.

Além do sentimento de deslumbramento do viajante aprendiz, há também nos diários do turista o estranhamento com a diferença, o desconforto de se lidar com um novo contexto:

Estou meio desapontado. Tudo a gente desconhece neste primeiro contato com a viagem, pessoas, corredores, decorações... Além do mais, me sinto muito urbano, chapéu de palha na cabeça, gravata longa embandeirando no vento... Vou pra cabina, abro a mala, tiro o boné... É extraordinário como as convenções gesticulam por nós. $E$ inda falam que o hábito não faz o monge... Bastou botar o boné na cabeça, olhei no espelho e era eu viajando. Fiquei fácil. Andei com certeza pelos deques, pude compreender o sabor das passadeiras e as colorações de bordo. Os outros viajantes inda não conheço não, porém viraram companheiros. (ANDRADE, 2015, p. 257).

O turista assume a permanente curiosidade e deslumbramento em relação ao outro, ao novo, ao diferente. Sua curiosidade impele-o a desvendar o mistério:

Nosso turista passa a ser aprendiz no instante em que vê algo que nenhum outro viu porque só a ele o mistério foi revelado. O mistério pode vir na forma mais simples possível. Essa é a experiência do rito: um homem travestido de baiana ri enquanto se requebra em frêmito e alegria desmedida. Mas lá no fundo, atrás de toda fantasia, de toda gargalhada e de todo rebolado frenético, o turista garimpa uma nesga de angústia. (PUCHEU, 2011, p.137).

A angústia, o desconforto, também fazem parte de qualquer viagem e não é diferente nas peripécias deste turista aprendiz. Quem viaja precisa estar preparado para o inesperado, para o desconfortável. O viajante alterna momentos de euforia e momentos de insegurança e tédio. Esta dualidade é característica de Mário de Andrade e este "pêndulo" emocional movimenta-se intensamente nos relatos contidos no "O turista aprendiz".

Então expliquei com muita paciência pra ele, espécie de explicação coletiva embora tardia, dada as centenas de pessoas que já tinham privado comigo nesta viagem, expliquei que não, que Rev. Caminhos da Educação: diálogos, culturas e diversidades, Teresina, v. 2, n. 3, p. 92-119, set./dez. 2020 
Aprender é uma viagem: reflexões marioandradianas sobre arte e educação

éramos um grupo de amigos paulistas, curiosos de conhecer outros brasis, viajando cada qual por conta própria, pela vaidade ou ventura de conhecer coisas. (ANDRADE, 2015, p. 156).

O grupo de amigos desta primeira viagem ao Norte, em 1927, era formado por Mário de Andrade, Olívia Guedes Penteado, Margarida Guedes Nogueira e Dulce do Amaral Pinto. Na passagem acima, Mário define que eram "um grupo de amigos paulistas, curiosos de conhecer outros brasis, viajando cada qual por conta própria, pela vaidade ou ventura de conhecer coisas".

\subsection{Diversidade}

Um tema constante das anotações nos diários do turista aprendiz é a diversidade. Diversidade de locais, pessoas e costumes encontrados ao longo do percurso.

Nos "Parques Infantis", Mário de Andrade demonstrou interesse pela diversidade de origens das crianças atendidas pelo projeto, que eram orientadas a escrever nome e nacionalidade atrás dos desenhos produzidos (GOBBI 2013). Também usou a diversidade de atividades como currículo: educação física, jogos, música, dança, leitura e desenho. Segundo Ana Lúcia Goulart de Faria, no livro "Educação Pré-escolar e Cultura":

Ao lado do folclore, jogos e brincadeiras eram as atividades principais do PI, fazendo com que as crianças participassem do projeto de construção da cultura nacional. MA acreditava que a criança não só aprende e consome a cultura do seu tempo, como também produz cultura, seja a cultura infantil de sua classe, seja reconstruindo a cultura à qual tem acesso. Provavelmente inspirado por suas leituras marxistas (analisadas por Ancona Lopes, 1972), Mário acreditava que todo ser humano produz cultura, faz história. Portanto, o povo e a elite, as crianças e os adultos, os negros, os índios e os portugueses, italianos etc. produzem e consomem cultura, influenciandose e construindo, na diversidade, a identidade nacional. (FARIA, 1999, p. 48).

Como viajante escritor, traçou muitas comparações entre os costumes e paisagens vistas no Norte e Nordeste e seus próprios costumes de "europeu cinzento Rev. Caminhos da Educação: diálogos, culturas e diversidades, Teresina, v. 2, n. 3, p. 92-119, set./dez. 2020 
e bem arranjadinho" (ANDRADE, 2015, p. 67) habitante de São Paulo. Como nesta passagem do dia 12 de janeiro de 1929, escrita durante sua permanência no Rio Grande do Norte:

Aliás desde minha viagem pelo Amazonas já reparei uma coisa curiosa: as tardes por aqui jamais são tristes. Uma diferença enorme das paulistas. Boca da noite, mesmo na fazenda de café mais agradável de paisagem, sempre é tristonha. Por aqui não. As mais largas, o sentimento que despertam é duma calma guaçu, do tamanho da morte, perfeitamente sossegada. Mas no geral são alegres, bem visíveis, um certo quê de espetacular muito refletido na psicologia do nordestino. (ANDRADE, 2015, p. 318).

Tardes tristes em São Paulo, mesmo "na fazenda de café mais agradável de paisagem". Tardes alegres no Nordeste e Norte, "um certo quê de espetacular". Além da paisagem, Mário também registrou nos diários a diversidade de costumes. Como no trecho abaixo, escrito em 7 de julho de 1927, no povoado de Três Casas, Amazônia:

Aqui, falam sempre jogar " $n$ ' água". Nós lá no sul falamos jogar "no lixo", jogar "na rua". É natural. Aqui a criançada vive n'água, cada um tem o seu casquinho, todos molhados. No sul, nem bem o filho chega perto do lavatorinho, a mãe logo se assusta:

- Menino! você se molha!

Imagino as mães por aqui, quando os filhos brincam com terra, ao sol, gritando logo:

- Menino! você se enxuga!

(ANDRADE, 2015, p. 148).

A diversidade de identidades das pessoas que cruzaram o caminho de Mário de Andrade também chamou a atenção do viajante nos diários. Como nesse registro em Tefé, Amazonas, em 30 de junho de 1927:

Naquela misturada de raças, pediram que assinássemos o livro das visitas, indicando as nacionalidades. Fulano: peruano; Sicrano: sírio; o dr. Tal, gaúcho; Schaeffer, suíço; Balança, paulista; Guarda da Alfândega, amazonense; Mário de Andrade, brasileiro. Dentre os brasileiros de bordo, fui o único brasileiro, sem querer. Vida de bordo. A peruada simpática, a americanada também. Vivemos mais com eles: os brasileiros são moral e fisicamente desengonçados. (ANDRADE, 2015, p. 134).

Nesta passagem, a questão chave do movimento modernista - a identidade brasileira - emerge. Em um embate entre nacionalismo e regionalismo, tema abordado neste artigo.

\subsection{Individual e coletivo}

Rev. Caminhos da Educação: diálogos, culturas e diversidades, Teresina, v. 2, n. 3, p. 92-119, set./dez. 2020 
A relação entre o que é individual e o que é coletivo perpassa a narração de Mário em "O turista aprendiz" e também aparece no projeto pedagógico "Parques Infantis", no direcionamento das atividades propostas. Nos diários de viagem, ao fazer uma escrita autoral, inventiva e em primeira pessoa, o escritor parte sempre de sua individualidade para a apresentar o mundo que o cerca. Sua concepção de arte interessada, com função social destaca o viés coletivo da arte, que muitas vezes tem origem na criação individual.

Em carta para Carlos Drummond de Andrade, Mário escreve sobre sua relação estreita com a coletividade, sobre o fato do seu trabalho só fazer sentido em face da coletividade. Carta escrita em São Paulo em 23 de agosto de 1925, dois anos antes da primeira viagem para o Norte do país:

É engraçado mas juro que é verdade: eu sou tão não-eu, tão os outros que tenho a certeza de ter falado a coisa mais certa de minha vida o dia em que afirmei não sei mais pra quem que a minha felicidade é feita de poucadinhos de felicidade alheia. É isso mesmo. Se vocês forem felizes eu fico sossegado, se forem idiotas a ponto de serem infelizes vai ser um desastre pra mim. (...) Felicidade na vida me parece que depende principalmente de duas coisas: a gente ser humano em vez de ser indivíduo e ter um conhecimento franco da vida. Ser humano acho que é a coisa mais fácil deste mundo porque somos provadamente sociais. Só não é humano quem é idiota. (ANDRADE, 1982, p. 40).

Portanto, esta relação interessada em face do "outro" é fundamental para se compreender a obra de Mário de Andrade. Sua relação com o "outro" constitui-se como base tanto do livro quanto do projeto educacional analisados nesta pesquisa. Tal concepção acerca da identidade brasileira baseia-se neste sentimento, ao construir uma ideia de identidade nacional que abarque o "outro", baseada na soma de diversas individualidades que constroem o todo chamado "brasilidade". Brasilidade que tem como principal característica a diversidade de identidades formadoras. 
No livro "O baile das quatro artes", ao refletir sobre a função social da arte no capítulo "O artista e o artesão", o autor reflete sobre a arte no século XX ter se deslocado de uma ênfase coletiva para uma ênfase individual. Escrito em 1938, período que Mário mudou-se para o Rio de Janeiro após ser demitido do Departamento de Cultura de São Paulo, este capítulo é a transcrição da sua aula inaugural dos cursos de Filosofia e História da Arte, do Instituto de Artes da Universidade do Distrito Federal, atual UFRJ. Vejamos um trecho, que Mário reflete sobre os artistas participantes do Salão de Maio, na cidade de São Paulo:

Há uma incongruência bem sutil em nosso tempo. Na história das artes, estamos num período que muito parece ter pesquisado e que, no entanto, é dos mais afirmativos, dos mais vaidosos, dos menos humildes diante da obra de arte. Há, por certo, em todos os artistas contemporâneos, uma desesperada, uma desapoderada vontade de acertar. Mas a inflação do individualismo, a inflação da estética experimental, a inflação do psicologismo, desnortearam o verdadeiro objeto da arte. Hoje, o objeto da arte não é mais a obra de arte, mas o artista. E não poderá haver maior engano. (ANDRADE, 1963, p. 32).

Ao fazer um balanço dos artistas participantes do Salão de Maio, Mário enfatiza o viés individualista das suas obras. "Hoje, o objeto da arte não é mais a obra de arte, mas o artista." Sobre esta afirmação, é difícil não pensar na arte do século XXI e o desdobramento dessa ideia de Mário, em que o objeto da arte se volta para o indivíduo. Como não pensar nas revistas que cobrem celebridades, em redes sociais, influenciadores digitais, no poder individual que adquirem os artistas e na força de sua própria imagem se comparada com a força de suas obras de arte? Ao que parece, esta tendência descrita por Mário há quase 100 anos atrás permaneceu e intensificou-se.

O deslumbramento com que Mário descreve a arte de Chico Antônio em passagens de "O turista aprendiz" revela a sua busca por um tipo de arte que relacione o indivíduo à coletividade. Algo que coloque o individual e o coletivo em relação. Arte que provém do indivíduo e que é absorvida pelo coletivo, tradicionalizando-se e apagando a figura do autor como ente individual e separado do todo:

Da mesma forma, em folclore, uma melodia, uma poesia, um passo de dança, nunca são inventados pelo povo, pela coletividade. Há sempre um indivíduo que por ser mais técnico, mais inventivo e mais audaz (o mais forte) crea a manifestação que, em seguida, o povo adopta (ou

\footnotetext{
${ }^{6}$ Chico Antônio, o coqueiro que tanto impressiona Mário de Andrade, torna-se personagem de seu romance inacabado Cafée de "Vida do Cantador", série que publica em seu rodapé "Mundo musical", na Folha da Manhã de São Paulo, em "seis lições", entre agosto e setembro de 1943. Rev. Caminhos da Educação: diálogos, culturas e diversidades, Teresina, v. 2, n. 3, p. 92-119, set./dez. 2020
} 


\section{Aprender é uma viagem: reflexões marioandradianas sobre arte e educação}

deixa de adoptar) e tradicionaliza, esquecido as mais das vezes o nome do mais forte que inventou o fato folclórico. (ANDRADE, 1941).

No livro "O turista aprendiz", Mário de Andrade faz de Chico Antonio um verdadeiro protagonista. Sobre o cantor, o escritor registra: "Não sabe que vale uma dúzia de Carusos. Vem da terra, canta por cantar, por uma cachaça, por coisa nenhuma e passa uma noite cantando sem parada. Já são 23 horas e desde as 19 que canta".

Figura 7 - Fotografia tirada por Mário de Andrade. O cantador Chico Antônio e seu acompanhador.

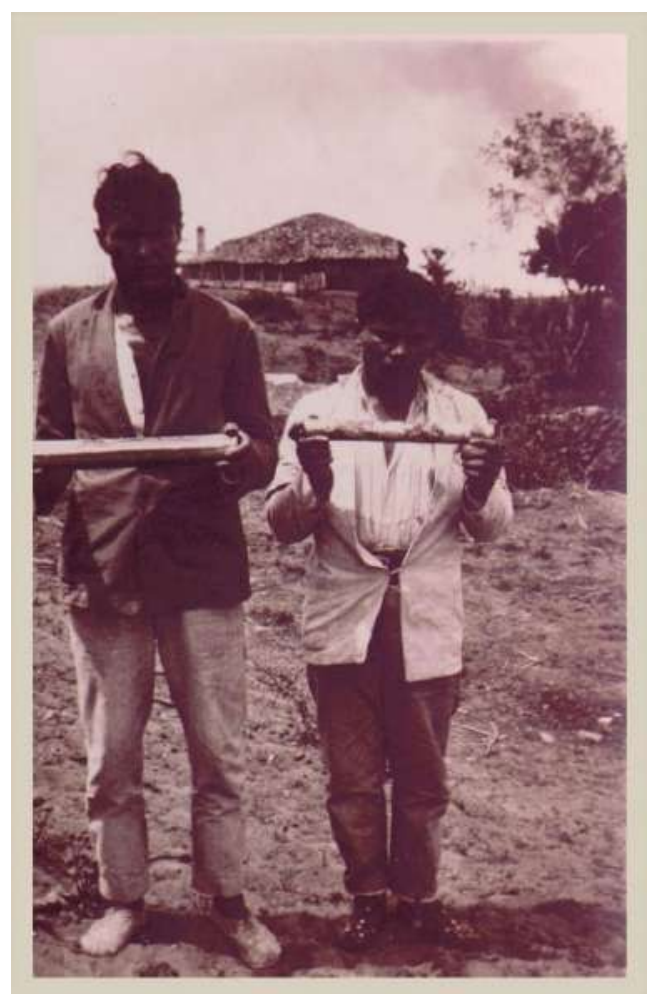

Legenda: Chico Antônio e o acompanhador dele/ Bom Jardim

Fonte: CD-ROM - Os Diários do Fotógrafo. Contido no livro "O Turista Aprendiz", Iphan, 2015. Número no CD-ROM: 1929- 188.

Rev. Caminhos da Educação: diálogos, culturas e diversidades, Teresina, v. 2, n. 3, p. 92-119, set./dez. 2020 
Para Mário de Andrade, Chico Antonio representa esta essência primitiva da arte, arte feita para o coletivo, arte que carrega "um profundo sabor evocativo, uma transcendência lírica, iluminada e fantasmática", como escreveu Mário ao referir-se às "criações dos artistas que independem da técnica, os primitivos em geral, os desenhos de crianças, os poemas dos loucos". Vejamos o trecho do livro "O baile das quatro artes":

É constante agora nas obras, desde o início do Oitocentos, por mais bem-compostas e dentro da técnica erudita, esse valor que encontramos com tanta frequência nas criações dos artistas que independem da técnica, os primitivos em geral, os desenhos de crianças, os poemas dos loucos: um profundo sabor evocativo, uma transcendência lírica, iluminada e fantasmática. (ANDRADE, 1963, p. 48).

Nos "Parques Infantis", os desenhos de crianças eram encarados como obras artísticas que representavam a identidade de seus autores. Identidades individuais que ajudariam a formar uma ideia de coletividade brasileira. A partir da diversidade de individualidades das crianças, Mário de Andrade quis compor um mosaico de Brasil, uma amostra experimental de como poderia ser formada a identidade brasileira.

Para Mário, a relação entre individual e coletivo aparece na própria gênese do fazer artístico:

A arte, srs. Alunos, é certo que nasce nos céus entusiásticos e fáceis da inspiração, gozo sublime e sensual do indivíduo. Mas logo em seguida a este gozo de um segundo, ela desce na terra desta nossa humanidade, e é o homem-operário, o homem-coletivo que sofre no trabalho perigoso e interrogativo de converter o êxtase do indivíduo num valor humano. O conseguirá?... Chopin confessa, de maneira muito clara, a consciência que tinha de que a arte é uma conversão do sentimento individual à sua expressão coletiva. Ele sabe muito bem que, se a arte nasce duma explosão do ser, a inteligência domina e conclui essa explosão improvisada. (ANDRADE, 1963, p.156).

Para o escritor, pensar em arte ou pensar em identidade brasileira passa por pensar na relação entre indivíduo e coletividade. Tanto no livro "O turista aprendiz" como no projeto "Parques Infantis" fica evidente a sua inspiração nesta dicotomia.

\section{Concluindo}

Baseado nas reflexões desta pesquisa, dentre as diretrizes pedagógicas propostas por Mário de Andrade para a educação infantil brasileira, destaco: o 
Aprender é uma viagem: reflexões marioandradianas sobre arte e educação

estímulo à imaginação, a exploração da relação entre o individual e o coletivo, conceber a criança como autora e valorizar a diversidade, que seria um traço relacionado à identidade nacional. Quase cem anos depois destas propostas, minha intenção ao realizar esta pesquisa não é interpretá-las para que sejam copiadas. Afinal, o contexto já não é mais o mesmo.

Recuperando os temas abordados em cada seção deste artigo, minha proposta é que nos inspiremos nestas diretrizes pedagógicas para balizar propostas educacionais que tomem a criança em sua autonomia criadora e respeitem a cultura infantil; estimulem sua imaginação e sensibilidade; entendam a viagem de uma perspectiva educativa e a educação sob uma ótica viajante; valorizem e criem espaço para a manifestação das diversidades; proponham uma reflexão sobre individual e coletivo. As novas tecnologias permitem abordagens múltiplas e potentes a partir destas diretrizes, que continuam atuais apesar do contexto ser outro, já que estamos na véspera das comemorações de cem anos da Semana de 1922. Mas podemos absorver ideias deste projeto de educação proposto por Mário de Andrade, adicionando a nossa contribuição e adaptando-o ao contexto que se apresenta atualmente.

Destas propostas, emerge como um dos pilares o deslocamento de Mário em direção ao "outro". A viagem é um deslocamento no sentido físico mas também no sentido figurado, Mário também realiza este deslocamento no livro "O turista aprendiz". Urge incluírmos o "outro", todos os "outros" que compõe a sociedade brasileira, no nosso projeto de educação nacional. A valorização da cultura popular, a colheita e registro de cantigas e poesias tradicionais, considerar festividades populares como patrimônio imaterial são atos inscritos nesta percepção e valorização do outro feita por Mário de Andrade. Que ela inspire práticas pedagógicas atuais e continue a ser uma diretriz em tempos de polarização política. Tempos em que o conceito do que significa ser "patriota” encontra-se em intensa disputa na sociedade brasileira.

Rev. Caminhos da Educação: diálogos, culturas e diversidades, Teresina, v. 2, n. 3, p. 92-119, set./dez. 2020 
A recuperação das ideias de Mário de Andrade pode constituir-se como referência para a criação de projetos de educação que valorizem a imaginação e a sensibilidade dos alunos, a diversidade e priorizem a relação entre o individual e o coletivo. A arte, tem papel fundamental neste processo, na missão de sensibilizar os alunos na percepção de sua identidade, da identidade do outro e do reconhecimento do ambiente vivido, iluminando as relações que se estabelecem entre indivíduo e coletividade na construção de uma sociedade brasileira mais justa e coesa, menos desigual. 


\section{REFERÊNCIAS BIBLIOGRÁFICAS}

ANDRADE, Carlos Drummond de. Confissões de Minas. São Paulo: Cosac Naify, 2011.

ANDRADE, Mário de. A Lição do Amigo: cartas de Mário de Andrade a Carlos Drummond de Andrade. Rio de Janeiro: J. Olympio, 1982.

ANDRADE, Mário de. A modinha e Lalo. São Paulo: Diários Associados, 28 jan., 1941.

ANDRADE, Mário de. Macunaíma: o herói sem nenbum caráter. Edição crítica de Telê Porto Ancona Lopez. Rio de Janeiro: Livros Técnicos e Científicos, 1978.

ANDRADE, Mário de. O baile das quatro artes. São Paulo: Martins Editora, 1963.

ANDRADE, Mário de. O Turista Aprendiæz; edição de texto apurado, anotada e acrescida de documentos por Telê Ancona Lopez, Tatiana Longo Figueiredo; Leandro Raniero Fernandes, colaborador. Brasília: Iphan, 2015.

FARIA, Ana Lucia G. Educação pré-escolar e cultura. Campinas: Unicamp/Cortez, 1999.

GOBBI, Márcia. Mário de Andrade e os Parques Infantis. São Paulo: Itaú Cultural, 2013.

MUNARI, Bruno. Il Laboratorio per Bambini a Brera. Bologna: Zanichelli: 1981.

MUNARI, Bruno. Fantasia. Lisboa: Edições 70, 2007.

PUCHEU, Alberto (org). O carnaval carioca de Mário de Andrade. Rio de Janeiro: Beco do Azougue, 2011.

ZUCCOLI, Franca. Educação \& Realidade, Porto Alegre, v. 40, n. 4, p. 1045-1060, out./dez. 2015.

RECEBIDO: 01/06/2020

APROVADO:03/08/ 2020
RECEIVED: $01 / 06 / 2020$

APPROVED: 03/08/ 2020
RECIBIDO: 03/08/ 2020

APROBADO: 03/08/ 2020 
https://doi.org/10.26694/caedu.v2i3.10869

ISSN 2675-1496

Rev. Caminhos da Educação: diálogos, culturas e diversidades, Teresina, v. 2, n. 3, p. 92-119, set./dez. 2020 